\title{
A Reason for Admission to the Sleep Outpatient Clinic during COVID-19 Pandemic: Insomnia
}

\author{
COVID-19 Pandemisi Sürecinde Uyku Polikliniğine Başvuru Nedeni: Uykusuzluk
}

\author{
Esra AYDIN SÜNBÜL ${ }^{1}$ \\ (1) 0000-0003-1864-9345 \\ Rahşan KARACI ${ }^{2}$ \\ (D) 0000-0003-2088-0087 \\ Füsun MAYDA DOMAÇ ${ }^{2}$ \\ (D) 0000-0003-3576-0344
}

\begin{abstract}
${ }^{1}$ Erenköy Mental Health and Neurological Diseases Training and Research Hospital Department of Psychiatry, Istanbul, Turkey

${ }^{2}$ Erenköy Mental Health and Neurological Diseases Training and Research Hospital, Department of Neurology, Istanbul, Turkey
\end{abstract}

\section{Corresponding Author Sorumlu Yazar \\ Esra AYDIN SÜNBÜL \\ dresraaydin@yahoo.com}

Received / Geliş Tarihi : 18.08 .2020 Accepted / Kabul Tarihi : 18.10.2020 Available Online /

Çevrimiçi Yayın Tarihi : 25.11.2020

\begin{abstract}
Aim: Sleep can be affected for various reasons such as social isolation, online education, shift work, etc. during the coronavirus disease 2019 (COVID-19) pandemic. People who have comorbid psychiatric or sleep disorders before the pandemic are thought to be more affected. The aim of this study was to investigate the effect of the COVID-19 pandemic on sleep quality and insomnia.

Material and Methods: Our study was a retrospective study, and patients who admitted to the sleep outpatient clinic with insomnia complaints during the COVID-19 pandemic were included. The complaints, sociodemographic characteristics, and diagnosis of the patients were obtained from medical records.

Results: Fifty-three patients diagnosed with insomnia according to the International Classification of Sleep Disorders third edition (ICSD-3) were included in the study. The mean sleep time before the pandemic was $6.8 \pm 1.2$ hours, while it was $5.9 \pm 1.7$ hours after the pandemic. After the pandemic, $13(24.5 \%)$ patients had shortened sleep duration. There was no difference in clinical features between those whose sleep duration decreased and did not change during the pandemic. Twenty $(37.7 \%)$ patients' complaints of insomnia started during the pandemic. Most of the patients whose complaints started during the pandemic were male $(n=12,60.0 \%)$. Their main complaint was difficulty in falling asleep $(n=18,90.0 \%)$. The anxiety symptoms were remarkable.

Conclusion: Sleep disorders during the pandemic are an important problem for everyone. However, some individuals have a higher risk of sleep problems. Therefore, the results of our study may contribute to the interventions aimed at improving sleep quality during pandemic. Keywords: COVID-19; insomnia; pandemic.
\end{abstract}

\section{ÖZ}

Amaç: Uyku, koronavirüs hastalığ 2019 (coronavirus disease 2019, COVID-19) pandemisi döneminde sosyal izolasyon, çevrimiçi eğitim, vardiyalı çalışma gibi çeşitli nedenlerle etkilenebilir. Pandemiden önce eşlik eden psikiyatrik veya uyku bozukluğu olan kişilerin bu durumdan daha fazla etkilendiği düşünülmektedir. $\mathrm{Bu}$ çalışmanın amacı COVID-19 pandemisinin uyku kalitesi ve uykusuzluk üzerine etkisini araştırmaktır.

Gereç ve Yöntemler: Çalışmamız geriye dönük bir çalışma olup COVID-19 pandemisi sürecinde uyku polikliniğine uykusuzluk yakınmasıyla başvuran hastalar çalışmaya dahil edilmiştir. Hastaların başvuru şikâyetleri, sosyo-demografik özellikleri ve tanıları tıbbi kayitlardan elde edildi.

Bulgular: Uluslararası Uyku Bozuklukları Sınıflandırmasının üçüncü baskısı (International Classification of Sleep Disorders third edition, ICSD-3)'na göre uykusuzluk tanısı almış 53 hasta çalışmaya dâhil edildi. Pandemiden önceki ortalama uyku süresi $6,8 \pm 1,2$ saat iken,

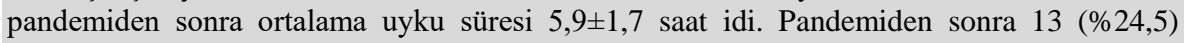
hastanın uyku süresi kısalmıştı. Pandemi sürecinde uyku süresi azalan ve değişmeyenler arasında klinik özellikler açısından fark yoktu. Yirmi $(\% 37,7)$ hastanın uykusuzluk şikâyeti pandemi döneminde başlamıştı. Pandemi sırasında yakınmaları başlayan hastaların çoğu $(\mathrm{n}=12, \% 60,0)$ erkekti. Başlıca şikâyetleri uykuya dalmada güçlüktü $(\mathrm{n}=18, \% 90,0)$. Şikâyetleri arasında anksiyete belirtileri dikkat çekiciydi.

Sonuç: Pandemi sırasındaki uyku problemleri herkes için önemli bir sorundur. Ancak bazı bireylerin uyku problemi geliştirme riski diğerlerinden daha yüksektir. Bu nedenle, çalışmamızın sonuçları pandemi dönemlerinde uyku kalitesini artırmaya yönelik bazı müdahalelerin uygulanmasına destek sağlayabilir.

Anahtar kelimeler: COVID-19; uykusuzluk; pandemi. 


\section{INTRODUCTION}

The coronavirus disease 2019 (COVID-19) pandemic is a virus outbreak that appeared on 1 December 2019. The spread rate of the virus increased in January 2020 and has spread all over the world. The first detected COVID-19 case was announced by the Ministry of Health in Turkey on 11 March 2020 (1).

Social isolation was applied in countries during the pandemic process. People left their homes only for food shopping and medical needs. All these restrictions affected people's lifestyles and social relationships. Anxiety increased in many people for fear of being infected (2). Studies show that psychological stress and mental illnesses increase during the pandemic period (3). Although the speed of virus spread has been reduced by restriction of freedom, working from home, and online education, their psychological reflections have been quite high.

Homeostatic drive to sleep is important for sleep quality. The circadian rhythm keeps us awake all day and sleepy at night. Factors such as sunshine, eating patterns and exercise regulate the circadian rhythm. The melatonin hormone has an important role in regulating sleep. Exposure to light throughout the day is needed to increase of melatonin during the night. Physical activity throughout the day improves sleep quality (4). Low activity levels (e.g., due to depression, social confinement) and very high activity levels (e.g., due to stress, work overload) affect sleep negatively. Causes such as working in shifts, circadian rhythm disturbances, inability to provide sufficient sleep time due to work and social factors cause short sleep durations (5).

It can be thought that sleep will be affected for various reasons during the pandemic period. This study aimed to investigate the effect of the COVID-19 pandemic on sleep quality and insomnia.

\section{MATERIAL AND METHODS}

This retrospective study was performed at the sleep outpatient clinic of Erenköy Mental and Neurological Diseases Training and Research Hospital. Following the Helsinki declaration, approval was obtained from the Ethics Committee of Erenköy Mental and Neurological Diseases Training and Research Hospital (08.06.2020, 12). After the emergence of the first case in our country, on 27.03.2020, patient admission started with new measures and arrangements in our sleep outpatient clinic. After two months of the epidemic, as of 01.06.2020, the normalization process has started. All patients who admitted to the sleep outpatient clinic with insomnia complaints between 27.03.2020 and 01.07.2020 were screened. Inclusion criteria included patients with diagnosis of insomnia according to the third edition of the International Classification of Sleep Disorders (ICSD-3), and those without any other accompanying sleep disorder. Exclusion criteria included patients with diagnosis of a sleep disorder other than insomnia. Fifty-three patients diagnosed with insomnia according to the ICSD-3 were included in the study. The complaints, sociodemographic characteristics, and diagnosis of the patients were obtained from medical records.

\section{Statistical Analysis}

Statistical analysis was performed using the SPSS v.20. The Shapiro-Wilk test was used to determine whether the data were normally distributed. Continuous data were expressed as mean and standard deviation or median, interquartile range and minimum-maximum values, while categorical data were presented as numbers and percentages. A student t test or Mann Whitney-U test was used to compare continuous variables with and without normal distribution, respectively. Pearson chi-square and Fisher's exact tests were used for statistical analysis of the categorical variables. A p value $<0.05$ was considered statistically significant.

\section{RESULTS}

The mean age of the patients was $44.1 \pm 14.1$ years. Twentynine $(54.7 \%)$ of the patients were male. The duration of the patients' complaints of insomnia was between 1 and 240 months (31.0 \pm 44.6$)$. The mean sleep time before the pandemic was $6.8 \pm 1.2$ hours, while the mean sleep time after the pandemic was $5.9 \pm 1.7$ hours. Of the 53 patients with insomnia, $48(90.6 \%)$ patients described difficulty in falling asleep, $19(35.8 \%)$ patients described difficulty in maintaining sleep, and $7(13.2 \%)$ patients described the problem of waking up early. Seventeen $(32.1 \%)$ patients complained of waking up tired in the morning. Twelve $(22.6 \%)$ patients had excessive sleepiness during the day, $14(26.4 \%)$ patients had depressive symptoms, 16 (30.2\%) patients had anxiety symptoms, $5(9.4 \%)$ patients had pain, $3(5.7 \%)$ patients had somatic complaints, and 7 (13.2\%) patients had irritability. Considering psychiatric comorbidities, there was a depressive disorder in $6(11.3 \%)$ patients, an anxiety disorder in $8(15.1 \%)$ patients, a psychotic disorder in 1 (1.9\%) patient, and a bipolar disorder in $3(5.7 \%)$ patients. Nineteen $(35.9 \%)$ patients were using antidepressants, $8(15.1 \%)$ patients were using anxiolytic, and $3(5.7 \%)$ patients were using antipsychotics. When other sleep disorders were examined, 1 (1.9\%) patient had REM behavior disorder, 1 (1.9\%) patient had nightmare disorder, and 1 (1.9\%) patient had sleep paralysis. When additional medical diseases were examined, $4(7.6 \%)$ patients had hypertension, $3(5.7 \%)$ patients had diabetes, $1(1.9 \%)$ patient had asthma, $1(1.9 \%)$ patient had chronic obstructive pulmonary disease, and 1 (1.9\%) patient had hypothyroidism. There were $1(1.9 \%)$ patient with alcohol use and $3(5.7 \%)$ smoking patients.

Patients were divided into two groups according to the presence of shortened sleep duration after the pandemic. While $13(24.5 \%)$ patients had shortened sleep duration, the sleep time of $40(75.5 \%)$ patients did not change. Patients with shortened sleep duration had significantly short insomnia duration $(\mathrm{p}=0.048)$. There was no difference in clinical features between the groups (Table 1).

Patients were divided into two groups according to the duration of the patient's complaints. While 20 (37.7\%) patients' complaints of insomnia started during the pandemic period, $33(62.3 \%)$ patients' complaints of insomnia started before the pandemic period. There was no difference in clinical features between the groups (Table 2). Most of the patients whose complaints started during the pandemic were male $(\mathrm{n}=12,60.0 \%)$. Their main complaint was difficulty falling asleep $(n=18,90.0 \%)$. Worry among their complaints was remarkable $(n=10,50.0 \%)$. Four of them had a diagnosis of anxiety disorder. Three of them had hypertension and two of them had diabetes mellitus. 
Table 1. Comparison of the patients with reduced and unchanged sleep time in pandemic

\begin{tabular}{|c|c|c|c|}
\hline & $\begin{array}{c}\text { Reduced } \\
(n=13)\end{array}$ & $\begin{array}{c}\text { Unchanged } \\
(n=40)\end{array}$ & $\mathbf{p}$ \\
\hline Age (years) & $44.4 \pm 10.3$ & $44.0 \pm 15.3$ & 0.937 \\
\hline Duration of insomnia (months) & $\begin{array}{c}2(6) \\
{[1-96]}\end{array}$ & $\begin{array}{l}36(52) \\
{[1-240]}\end{array}$ & 0.048 \\
\hline \multicolumn{4}{|l|}{ Gender } \\
\hline $\begin{array}{l}\text { Male } \\
\text { Female }\end{array}$ & $\begin{array}{l}5(38.5) \\
8(61.5)\end{array}$ & $\begin{array}{l}24(60.0) \\
16(40.0)\end{array}$ & 0.175 \\
\hline Increased insomnia complaint & $5(38.5)$ & $16(40.0)$ & 0.922 \\
\hline Waking up early & $2(15.4)$ & $5(12.5)$ & 0.790 \\
\hline Difficulty maintaining sleep & $7(53.8)$ & $12(30.0)$ & 0.183 \\
\hline Difficulty falling asleep & $12(92.3)$ & $36(90.0)$ & 0.805 \\
\hline Tired waking up & $7(53.8)$ & $10(25.0)$ & 0.086 \\
\hline Daytime sleepiness & $2(15.4)$ & $10(25.0)$ & 0.707 \\
\hline Headache & $1(7.7)$ & $4(10.0)$ & 0.805 \\
\hline Depressive symptoms & $2(15.4)$ & $12(30.0)$ & 0.473 \\
\hline Anxiety symptoms & $4(30.8)$ & $12(30.0)$ & 0.958 \\
\hline Ache & $1(7.7)$ & $4(10.0)$ & 0.805 \\
\hline Somatic complaint & $0(0.0)$ & $3(7.5)$ & 0.567 \\
\hline Irritability & $0(0.0)$ & $7(17.5)$ & 0.174 \\
\hline Depressive disorder & $1(7.7)$ & $5(12.5)$ & 0.635 \\
\hline Anxiety disorder & $2(15.4)$ & $6(15.0)$ & 0.973 \\
\hline Psychotic disorder & $1(7.7)$ & $0(0.0)$ & 0.245 \\
\hline Bipolar disorder & $0(0.0)$ & $3(7.5)$ & 0.567 \\
\hline Hypertension & $1(7.7)$ & $3(7.5)$ & 0.982 \\
\hline Diabetes Mellitus & $2(15.4)$ & $1(2.5)$ & 0.145 \\
\hline Asthma & $0(0.0)$ & $1(2.5)$ & 0.565 \\
\hline $\begin{array}{l}\text { Chronic Obstructive } \\
\text { Pulmonary Disease }\end{array}$ & $1(7.7)$ & $0(0.0)$ & 0.245 \\
\hline Hypothyroidism & $0(0.0)$ & $1(2.5)$ & 0.565 \\
\hline
\end{tabular}

Reduced: patients with reduced sleep time in pandemic, Unchanged: patients with no change of sleep time in pandemic, data are presented as the number $(\%)$ of patients, mean \pm standard deviation or median (interquartile range) [minimum-maximum]

\section{DISCUSSION}

Stress-related sleep problems are quite common (6). The group that is sensitive to stress-related sleep disorders generally develops chronic insomnia (7). Preexisting insomnia is an important risk factor for Posttraumatic Stress Disorder (PTSD) (8). This stressor causes the sleep disorder to increase even more (9). In our study, $37.7 \%$ of the patients had newly developed insomnia while $62.3 \%$ of the patients had insomnia before the COVID-19 pandemic. Studies on acute infectious diseases such as severe acute respiratory syndrome (SARS) show that both the infected and uninfected developed anxiety, depression, stress, and posttraumatic stress disorder $(10,11)$. In previous studies, it has been shown that sudden developing events have negative effects on people's mental health and cause symptoms similar to post-traumatic stress disorder (12). In a newly published study, $7 \%$ of people living in Wuhan, most of whom were female experienced PTSD symptoms during the COVID-19 pandemic (13). In our study, the majority of our patients who suffered from insomnia both during and before the pandemic period were female.
Table 2. Comparison of the patients according to the time of the complaints start

\begin{tabular}{|c|c|c|c|}
\hline & $\begin{array}{l}\text { During the } \\
\text { pandemic } \\
(n=20)\end{array}$ & $\begin{array}{c}\text { Before the } \\
\text { pandemic } \\
(\mathbf{n}=33)\end{array}$ & $\mathbf{p}$ \\
\hline Age (years) & $40.0 \pm 11.1$ & $46.6 \pm 15.3$ & 0.099 \\
\hline Duration of insomnia (months) & $\begin{array}{l}1(1) \\
{[1-2]}\end{array}$ & $\begin{array}{c}36(36) \\
{[13-240]}\end{array}$ & $<0.001$ \\
\hline \multicolumn{4}{|l|}{ Gender } \\
\hline $\begin{array}{l}\text { Male } \\
\text { Female }\end{array}$ & $\begin{array}{c}12(60.0) \\
8(40.0)\end{array}$ & $\begin{array}{l}17(51.5) \\
16(48.5)\end{array}$ & 0.547 \\
\hline Waking up early & $3(15.0)$ & $4(12.1)$ & 0.764 \\
\hline Difficulty maintaining sleep & $8(40.0)$ & $11(33.3)$ & 0.624 \\
\hline Difficulty falling asleep & $18(90.0)$ & $30(90.9)$ & 0.913 \\
\hline Tired waking up & $6(30.0)$ & $11(33.3)$ & 0.801 \\
\hline Daytime sleepiness & $2(10.0)$ & $10(30.3)$ & 0.105 \\
\hline Headache & $2(10.0)$ & $3(9.1)$ & 0.913 \\
\hline Depressive symptoms & $5(25.0)$ & $9(27.3)$ & 0.856 \\
\hline Anxiety symptoms & $10(50.0)$ & $6(18.2)$ & 0.014 \\
\hline Ache & $2(10.0)$ & $3(9.1)$ & 0.913 \\
\hline Somatic complaint & $1(5.0)$ & $2(6.1)$ & 0.871 \\
\hline Irritability & $4(20.0)$ & $3(9.1)$ & 0.405 \\
\hline Depressive disorder & $1(5.0)$ & $5(15.2)$ & 0.390 \\
\hline Anxiety disorder & $4(20.0)$ & $4(12.1)$ & 0.457 \\
\hline Psychotic disorder & $1(5.0)$ & $0(0.0)$ & 0.377 \\
\hline Bipolar disorder & $2(10.0)$ & $1(3.0)$ & 0.549 \\
\hline Hypertension & $3(15.0)$ & $1(3.0)$ & 0.145 \\
\hline Diabetes Mellitus & $2(10.0)$ & $1(3.0)$ & 0.549 \\
\hline Asthma & $0(0.0)$ & $1(3.0)$ & 0.432 \\
\hline $\begin{array}{l}\text { Chronic Obstructive } \\
\text { Pulmonary Disease }\end{array}$ & $0(0.0)$ & $1(3.0)$ & 0.432 \\
\hline Hypothyroidism & $0(0.0)$ & $1(3.0)$ & 0.432 \\
\hline
\end{tabular}

During the pandemic: insomnia started in the pandemic, Before the pandemic: insomnia started before the pandemic, data are presented as the number $(\%)$ of patients, mean \pm standard deviation or median (interquartile range) [minimum-maximum]

Anxiety levels of those who were younger than 35 years and followed more than 3 hours of COVID-19 news per day were found to be higher than those who were older than 35 and less exposed to COVID-19 news (13). We detected that patients who developed insomnia during the pandemic period were younger than those who developed insomnia before the pandemic $(40.0 \pm 11.1$ vs. $46.6 \pm 15.3)$. Studies have shown that PTSD symptoms develop less in the presence of good sleep quality and fewer early morning awakening (14). In our study, 7 of the patients diagnosed with insomnia had early morning awakening.

In a study by Taylor et al. (15) in 2008, it was shown that young age and female gender caused negative psychological effects in the quarantine period. In another study, the presence of psychiatric illness was shown to be associated with anxiety and anger 4-6 months after quarantine (16). There was a depressive disorder in 6 $(11.3 \%)$ patients, an anxiety disorder in $8(15.1 \%)$ patients, a psychotic disorder in $1(1.9 \%)$ patient, and a bipolar disorder in $3(5.7 \%)$ patients in our study. 
Sleep has important effects on the immune system and emotion regulation. Studies on sleep deprivation have shown the relationship between the immune system and sleep. Cohen et al. (17) show that those with sleep time $<7$ hours or sleep efficiency $<92 \%$ had more infections after virus exposure than those with sleep time $>8$ hours or sleep efficiency $>98 \%$. In a study, it was shown that the risk of having a cold after a virus exposure increased in those who sleep less than 6 hours a night (18). In our patients, the mean sleep time before the pandemic was $6.8 \pm 1.2$ hours, while the mean sleep time after the pandemic was $5.9 \pm 1.7$ hours. This is important for vulnerability to infection.

There is a review by the European CBT-I Academy that examines sleep and insomnia due to COVID-19 home confinement (19). Cellini et al. (20) evaluated the sleep structure, time perception, and use of electronic devices in 1310 people and saw an increase in the use of social media before bedtime. They saw that people go to bed later, get up later, and spend more time in bed, thus reducing sleep quality. Sleep problems have been shown to increase in the presence of depression, anxiety, and stress. Li et al. (21) demonstrated an increased prevalence of insomnia, including new-onset insomnia, during the COVID-19 pandemic. While time in bed and total sleep time increased, sleep efficiency decreased significantly (21). In our study, while patients described a higher rate of difficulty in falling asleep, early morning awakening rates were low.

As in the COVID-19 outbreak, traumatic events cause psychological stress and anxiety and affect sleep quality (22). For that reason, studies conducted during the COVID-19 pandemic focused on physical and mental health and sleep disorders. Consistent with these studies, in our study, $14(26.4 \%)$ patients had depressive symptoms, $16(30.2 \%)$ patients had anxiety symptoms, 7 (13.2\%) patients had irritability, and $3(5.7 \%)$ patients had somatic complaints.

In most studies conducted during the COVID-19 pandemic period, a specific sleep scale was not used. Most of the studies have been done by medical staff, who are exposed to or suffered from the virus itself (22). In our study, a specific sleep scale was not used, either. However, since patients who admitted to the sleep outpatient clinic are examined, it is important in terms of providing information about the society.

\section{CONCLUSION}

Sleep disorders during the pandemic period are an important problem for everyone. However, some individuals are riskier for sleep problems. Female gender, comorbid psychiatric disorders, and medical illness are important risk factors. Since sleep affects both emotional regulation and the immune system, it is very important during the pandemic period. Good sleep is necessary for psychological well-being and a strong immune system. Therefore, the results of our study may contribute to interventions aimed at improving sleep quality during pandemic periods. Providing psychological support in risky groups such as female gender, additional medical and psychiatric diseases, and training to improve sleep quality is very important. It is necessary to maintain the normal routine during pandemic periods to regulate the circadian rhythm.
Ethics Committee Approval: The study was approved by the Ethics Committee of Erenköy Mental and Neurological Diseases Training and Research Hospital (08.06.2020, 12).

Conflict of Interest: None declared by the authors.

Financial Disclosure: None declared by the authors.

Acknowledgements: None declared by the authors.

\section{REFERENCES}

1. Budak F, Korkmaz Ş. An overall evaluation for the COVID-19 pandemic process: the case of Turkey. Journal of Social Research and Management. 2020;1:62-79.

2. Giallonardo V, Sampogna G, Del Vecchio V, Luciano M, Albert U, Carmassi C, et al. The impact of quarantine and physical distancing following COVID19 on mental health: study protocol of a Multicentric Italian Population Trial. Front Psychiatry. 2020;11:533.

3. Bao Y, Sun Y, Meng S, Shi J, Lu L. 2019-nCoV epidemic: address mental health care to empower society. Lancet. 2020;395(10224):e37-8.

4. Fuller PM, Gooley JJ, Saper CB. Neurobiology of the sleep-wake cycle: Sleep architecture, circadian regulation, and regulatory feedback. J Biol Rhythms. 2006;21(6):482-93.

5. Taylor DJ, Lichstein KL, Durrence HH. Insomnia as a health risk factor. Behav Sleep Med. 2003;1(4):227-47.

6. Altena E, Micoulaud-Franchi JA, Geoffroy PA, SanzArigita E, Bioulac S, Philip P. The bidirectional relation between emotional reactivity and sleep: From disruption to recovery. Behav Neurosci. 2016;130(3):336-50.

7. Akerstedt T, Kecklund G, Axelsson J. Impaired sleep after bedtime stress and worries. Biol Psychol. 2007;76(3):170-3.

8. Gehrman P, Seelig AD, Jacobson IG, Boyko EJ, Hooper TI, Gackstetter GD, et al. Predeployment sleep duration and insomnia symptoms as risk factors for new-onset mental health disorders following military deployment. Sleep. 2013;36(7):1009-18.

9. Miller KE, Brownlow JA, Woodward S, Gehrman PR. Sleep and dreaming in posttraumatic stress disorder. Curr Psychiatry Rep. 2017;19(10):71.

10. Hawryluck L, Gold WL, Robinson S, Pogorski S, Galea S, Styra R. SARS control and psychological effects of quarantine, Toronto, Canada. Emerg Infect Dis. 2004;10(7):1206-12.

11. Wu KK, Chan SK, Ma TM. Posttraumatic stress after SARS. Emerg Infect Dis. 2005;11(8):1297-300.

12. Mak IW, Chu CM, Pan PC, Yiu MG, Ho SC, Chan VL. Risk factors for chronic post-traumatic stress disorder (PTSD) in SARS survivors. Gen Hosp Psychiatry. 2010;32(6):590-8.

13. Huang Y, Zhao N. Generalized anxiety disorder, depressive symptoms and sleep quality during COVID-19 epidemic in China: A web-based crosssectional survey. Psychiatry Res. 2020;288:112954.

14. Liu N, Zhang F, Wei C, Jia Y, Shang Z, Sun L, et al. Prevalence and predictors of PTSS during COVID-19 outbreak in China hardest-hit areas: Gender differences matter. Psychiatry Res. 2020;287:112921. 
15. Taylor MR, Agho KE, Stevens GJ, Raphael B. Factors influencing psychological distress during a disease epidemic: data from Australia's first outbreak of equine influenza. BMC Public Health. 2008;8:347.

16. Jeong H, Yim HW, Song YJ, Ki M, Min JA, Cho J, et al. Mental health status of people isolated due to Middle East Respiratory Syndrome. Epidemiol Health. 2016;38:e2016048.

17. Cohen S, Doyle WJ, Alper CM, Janicki-Deverts D, Turner RB. Sleep habits and susceptibility to the common cold. Arch Intern Med. 2009;169(1):62-7.

18. Prather AA, Janicki-Deverts D, Hall M, Cohen S. Behaviorally assessed sleep and susceptibility to the common cold. Sleep. 2015;38(9):1353-9.

19. Altena E, Baglioni C, Espie CA, Ellis J, Gavriloff D, Holzinger B, et al. Dealing with sleep problems during home confinement due to the COVID-19 outbreak: practical recommendations from a task force of the European CBT-I Academy. J Sleep Res. 2020;[Epub ahead of print]. doi: 10.1111/jsr.13052.

20. Cellini N, Canale N, Mioni G, Costa S. Changes in sleep pattern, sense of time and digital media use during COVID-19 lockdown in Italy. J Sleep Res. 2020;[Epub ahead of print]. doi: 10.1111/jsr.13074.

21. Li Y, Qin Q, Sun Q, Sanford LD, Vgontzas AN, Tang $\mathrm{X}$. Insomnia and psychological reactions during the COVID-19 outbreak in China. J Clin Sleep Med. 2020;16(8):1417-8.

22. Brooks SK, Webster RK, Smith LE, Woodland L, Wessely S, Greenberg N, et al. The psychological impact of quarantine and how to reduce it: rapid review of the evidence. Lancet. 2020;395(10227):912-20. 